\title{
TANTANGAN PROFESI GURU PENDIDIKAN AGAMA BUDDHA DI TANGERANG
}

\author{
Oleh: \\ Sugianto \\ STABN Sriwijaya Tangerang Banten \\ sugianto@stabn-sriwijaya.ac.id
}

\begin{abstract}
The purpose of this article is to describe profession challenges of the Buddhist religion teacher in Tangerang. The method used in this study is descriptive qualitative. The study was conducted from March to June 2018 to Buddhist religion teacher in Tangerang. Data is collected through interviews. Validity of data by credibility, dependability, confirmability and transferbility tests. Data analysis using the Miles $\mathcal{E}$ Huberman model. Based on the results of research profession challenges of the Buddhist religion teacher in Tangerang is related to evocative, quality students, character building, reduced number of students, and educational facilities. To uncover these challenges, teachers will conduct quality learning through cooperative learning methods, the use of contemporary learning media, patience and caution in dealing with students, and provide additional assignments to attend a Buddhist Sunday school or devotional service.
\end{abstract}

Keywords: profession challenges of the Buddhist religion teacher

\section{PENDAHULUAN}

Tuntutan terhadap kualitas pendidikan agama Buddha meningkat sejalan dengan perkembangan ilmu pengetahuan, teknologi, dan seni. Pendidikan Agama Buddha (PAB) diharapkan dapat menyiapkan peserta didik yang mampu hidup dengan benar di tengah-tengah perkembangan dunia yang sangat pesat, dan tidak menjadi korban dampak negative dari perkembangan dunia. Melalui pendidikan agama Buddha, masyarakat memberikan kepercayaan yang besar kepada sekolah untuk mendidik anak menjadi manusia yang bermoral, berkeyakinan, dan menjadi warga masyarakat yang bertanggung jawab. Oleh karena itu, proses pembelajaran Pendidikan Agama Buddha menjadi bagian penting untuk membangun karakter anak dengan menanamkan nilai-nilai luhur dalam ajaran Buddha agar dapat tumbuh kembang dengan baik seiring dengan kemajuan jaman. Tuntutan terhadap kualitas pendidikan agama Buddha menjadi tantangan bagi guru Pendidikan Agama Buddha

Salah satu faktor utama yang menentukan kualitas pembelajaran PAB adalah guru. Guru menjadi orang yang memiliki peran besar dalam mengelola suatu pembelajaran agar berjalan dengan baik dan dapat mencapai tujuan pembelajaran. Kompetensi guru menjadi faktor utama yang akan menentukan arah pembelajaran dan ketercapaian tujuan pembelajaran. Peran guru Pendidikan Agama Buddha (PAB) menjadi vital, karena bila salah dalam mengelola pembelajaran tidak hanya berpengaruh pada kegagalan dalam 
proses pembelajaran tetapi juga pada kegagalan siswa dalam menjalani proses kehidupan. Hal ini dikarenakan pembelajaran PAB penuh dengan nilai-nilai yang tidak cukup hanya disampaikan secara yang tekstual, tetapi juga perlu disampaikan secara kontekstual. Melalui pembelajaran PAB, berbagai isu yang sedang berkembang di sekitar lingkungan anak dijadikan bahan atau materi pembelajaran agar siswa memiliki pandangan yang benar sesuai dengan perspektif ajaran Buddha serta mampu menyikapinya dalam bentuk perilaku atau penghidupan yang benar.

Sejalan dengan tuntutan terhadap mutu pendidikan PAB, peran guru PAB pun semakin beragam untuk memastikan agar pembelajaran terlaksana dengan baik. Guru agama Buddha tidak lagi berperan sebagai sumber pembelajaran tunggal yang mendominasi materi pembelajaran. Saat ini guru telah berubah peran, tak lagi sebagai satu-satunya sumber belajar siswa tetapi guru memfasilitasi siswa belajar dari berbagai sumber belajar. Selain itu, guru juga punya peran lain seperti motivator, inspirator, pendidik, pelatih, pembimbing, pengarah, dan penilai, serta pengevaluasi. Oleh karena itu, guru harus berupaya menunjukkan kemampuan terbaik agar mampu menjalankan peran dan tugas dengan baik, standar kompetensi guru mutlak harus dipenuhi oleh semua guru PAB.

Pada saat ini, standar kualifikasi guru PAB adalah minimal seorang sarjana pendidikan agama Buddha yang menguasai empat standar kompetensi guru yaitu kompetensi pedagogik, kompetensi kepribadian, kompetensi sosial, dan kompetensi professional. Keempat standar kompetensi menjadi standar kerja yang harus dimiliki guru. Guru PAB yang merupakan seorang Sarjana Pendidikan (S.Pd.) dari perguruan tinggi keagamaan Buddha yang menguasai empat standar kompetensi. Dengan demikian dapat diharapkan menunjukan kinerja yang baik dalam melaksanakan tugas dan tanggung jawab.

Tanpa menguasai keempat kompetensi, guru PAB akan mengalami masalah yang merugikan diri sendiri, siswa, masyarakat, dan perkembangan agama Buddha. Guru dapat mengajarkan hal-hal yang kurang tepat, salah dalam membimbing dan mengarahkan siswa, mutu pendidikan akan turun, dan tidak dipercaya masyarakat. Siswa dapat memiliki pemahaman yang salah. Oleh karena itu, guru PAB harus senantiasa termotivasi mengembangkan kemampuan terbaik. Guru terus belajar untuk menambah pengetahuan dan keterampilan agar tidak ketinggalan jaman, di sisi lain guru juga terus menjaga kepribadian yang luhur serta mampu berinteraksi sosial dengan baik sesuai dengan perkembangan jaman seperti halnya yang dilakukan oleh guru PAB di Tangerang.

Tangerang merupakan salah satu wilayah di Provinsi Banten yang memiliki guru PAB dalam jumlah yang banyak. Hal tersebut dikarenakan jumlah siswa yang beragama Buddha dari jenjang pendidikan dasar sampai menengah banyak dan pembelajaran PAB banyak diselenggarakan di sekolah di wilayah Tangerang dari tingkat sekolah dasar, sekolah menengah pertama, hingga sekolah menengah atas atau sekolah menengah kejuruan. Sebagian guru PAB di Tangerang sudah tersertifikasi dan sebagian lagi belum 
tersertifikasi. Meskipun terdapat perbedaan status antara guru tersertifikasi dengan guru belum tersertifikasi, namun pada umumnya masyarakat memiliki harapan yang sama bahwa pembelajaran PAB dilaksanakan secara berkualitas. Oleh karena itu, guru PAB baik yang tersertifikasi maupun belum tersertifikasi wajib mengembangkan diri agar mampu memenuhi harapan masyarakat. Artikel ini disusun untuk mendeskripsikan tantangan profesi guru Pendidikan Agama Buddha.

\section{KAJIAN TEORI}

\section{Pengertian Profesi Guru Agama Buddha (PAB)}

Profesi adalah suatu jabatan yang memerlukan kemampuan intelektual khusus, yang diperoleh melalui kegiatan belajar dan pelatihan yang bertujuan untuk menguasai keterampilan dan keahlian dalam melayani dan memberikan saran atau nasihat pada orang lain; memperoleh upah atau gaji dalam jumlah tertentu (Danim, 2013: 8). Berdasarkan pengertian tersebut, guru (PAB) merupakan salah satu profesi karena untuk menjadi guru harus terlebih dahulu mengambil pendidikan di perguruan tinggi keagamaan Buddha hingga menjadi sarjana dan guru PAB juga mendapatkan gaji atau upah sebagai bentuk penghargaan terhadap kinerja guru.

Selanjutnya, menurut UU Nomor 14 tahun 2005 disebutkan prinsipprinsip guru sebagai profesi yaitu: (a) memiliki bakat, minat, panggilan jiwa, dan idealisme; (b) memiliki komitmen untuk meningkatkan mutu pendidikan, keimanan, ketakwaan, dan akhlak mulia; (c) memiliki kualifikasi akademik dan latar belakang pendidikan sesuai dengan bidang tugas; (d) memiliki kompetensi yang diperlukan sesuai dengan bidang tugas; (e) memiliki tanggung jawab atas pelaksanaan tugas keprofesionalan; (f) memperoleh penghasilan yang ditentukan sesuai dengan prestasi kerja; (g) memiliki kesempatan untuk mengembangkan keprofesionalan secara berkelanjutan dengan belajar sepanjang hayat; (h) memiliki jaminan perlindungan hukum dalam melaksanakan tugas keprofesionalan; dan (i) memiliki organisasi profesi yang mempunyai kewenangan mengatur hal-hal yang berkaitan dengan tugas keprofesionalan guru. Berdasarkan prinsip tersebut, pekerjaan guru tidak dapat dilakukan oleh sembarang orang, melainkan butuh orang yang memiliki pengetahuan, keterampilan yang sesuai dengan bidang ajar, memiliki karakter yang baik, dan keberadaanya diakui masyarakat, hukum, dan organisasi.

Mengacu pada kronologi hidup Buddha Gotama, Buddha Gotama merupakan figur guru ideal. Buddha menunjukkan dedikasi yang luar biasa dalam membabarkan Dhamma yang indah pada awalnya, indah pada pertengahannya, dan indah pada akhirnya demi kebahagiaan dan kesejahteraan semua makhluk. Selama 45 tahun Buddha membabarkan Dhamma kepada banyak makhluk baik itu manusia, dewa, maupun brahma. Keberhasilan beliau mengajar salah satunya dibuktikan dengan keberhasilan para siswa mencapai tingkat kesucian Arahat. (Kusaladhamma, 2009). 


\section{Standar Kompetensi Guru}

Ada tiga kritera kompetensi guru menurut Conny R. Semiawan dalam Danim (2013: 10 - 11) yaitu knowledge criteria, performance criteria, dan product criteria. Knowledge criteria adalah kemampuan intelektual dalam penguasaan materi pelajaran, cara mengajar, tingkah laku individu, bimbingan dan penyuluhan, kemasyarakatan dan pengetahuan umum. Performance criteria adalah kemampuan guru dalam bentuk keterampilan dan perilaku, seperti terampil mengajar, membimbing, menilai, menggunakan media, bergaul, berkomunikasi, terampil menyususn persiapan dan perencanaan pembelajaran. Product criteria adalah kemampuan guru dalam mengukur kemampuan dan kemajuan siswa setelah mengkikuti pembelajaran.

Sementara dalam Permendiknas Nomor 16 tahun 2007 dijabarkan empat kompetensi guru, yaitu kompetensi pedagogik, kompetensi sosial, kompetensi kepribadian dan kompetensi professional. Keempat kompetensi tersebut menjadi standar kerja yang harus dipahami, dimiliki, dihayati dan dilaksanakan oleh guru termasuk guru PAB.

Standar kompetensi guru dibuat dengan tujuan untuk menjamin dikuasainya tingkat kompetensi minimal oleh guru sehingga yang bersangkutan dapat melaksanakan tugasnya secara professional, dapat dibina secara efektif dan efisien, serta dapat melayani pihak yang berkepentingan sesuai dengan bidang tugasnya (Fathurohman dan Suryana, 2012: 33). Mengacu pada hal itu, guru tidak cukup hanya berusaha mencapai standar kompetensi, namun lebih dari itu guru dapat meningkatkan kompetensi di atas standar yang telah ditentukan.

\section{Tugas dan Peran Guru}

Berdasarkan UU No. 14 Tahun. 2005 tentang Guru dan Dosen yang disebut guru adalah pendidk pada pendidikan anak usia dini jalur pendidikan formal, pendidikan dasar, dan pendidikan menengah, yang memiliki tugas utama: mendidik, mengajar, membimbing, mengarahkan, melatih, menilai, dan mengevaluasi peserta didik. Untuk menjalankan tugas tersebut, guru memiliki berbagai peran dalam pembelajaran.

Menurut Mulyasa (2009), dalam melaksanakan tugas profesi, guru menjalankan berbagai macam peran antara lain: pendidik, pengajar, pembimbing, pelatih, penasehat, pembaharu, model dan teladan, pendorong kreativitas, aktor, emansipator, dan evaluator. Peran-peran guru tersebut disesuaikan dengan situasi yang timbul pada saat pembelajaran.

Menurut Buddhisme, guru memiliki kewajiban kepada siswa antara lain dalam memberikan instruksi harus jelas agar dipahami siswa, guru mengulang kembali materi yang disampaikan agar siswa benar-benar paham, guru melatih keterampilan yang berguna bagi siswa, dan memberi rasa aman. Berdasarkan tugas tersebut, tugas guru tidak hanya terkait pembelajaran tapi juga di luar pembelajaran guru menunjukkan perhatian untuk kemajuan dan keamanan siswa. (Sigalaka Sutta, Digha Nikaya). 
Di kesempatan lain Buddha juga memberikan penjelasan pentingnya guru untuk meningkatkan kompetensi diri agar tidak di cela. Dalam Lohicca Sutta, Digha Nikaya, Buddha menjelaskan salah satu sebab guru akan dicela bila guru belum menguasai materi dengan baik tetapi sudah mengajarkan kepada siswa. Sedangkan guru tidak akan dicela bila telah menguasai materi dengan baik dan memiliki moralitas yang baik kemudian mengajarkan kepada siswa dan siswa tersebut berhasil menguasai materi seperti yang diajarkan guru dan memiliki moralitas yang baik. Berdasarkan kriteria tersebut, ilmu dan moralitas memiliki peran penting dimiliki guru.

Untuk menjalankan peran dan tugas tersebut, guru PAB menghadapi berbagai permasalahan dalam hal pembelajaran, kepribadian, sosial, maupun penguasaan materi. Ini merupakan tantangan dalam profesi guru PAB. Dengan memiliki kompetensi yang baik, berbagai tantangan dalam profesi guru dapat diatasi dengan baik. Sebaliknya jika guru tidak menguasai standar kompetensi akan mengalami hambatan dalam melaksanakan tugas dan tanggung jawab sebagai guru PAB.

Penelitian yang relevan dengan penelitian ini adalah Profesionalisme Guru dan Tantangan Kedepan dalam Peningkatan Mutu Pendidikan Pada Era Global oleh Aziz Shofi Nurdiansyah, Mahasiswa Pascasarjana Universitas Negeri Malang. Hasil dari penelitian ini adalah tantanggan profesinalisme guru kedepan adalah perkembangan teknologi informasi, desentralisasi dan sentralisasi pendidikan, dan pasar bebas ASEAN.

\section{METODE PENELITIAN}

Penelitian ini termasuk jenis penelitian deskriptif kualitatif. Peneliti mendeskripsikan macam-macam tantangan yang dihadapi guru PAB dan cara menghadapi tantangan tersebut. Penelitian dilaksanakan di wilayah Tangerang. Obyek penelitian adalah tantangan profesi guru PAB. Subyek penelitian adalah guru $\mathrm{PAB}$ yang sudah tersertifikasi dan yang belum tersertifikasi di sekolah negeri atau swasta. Waktu penelitian dimulai pada bulan Maret sampai dengan Juni 2018. Teknik pengumpulan data dengan menggunakan wawancara. Untuk menguji keabsahan data dilakukan dengan uji kredibilitas, dependabilitas, konfirmabilitas, dan transferbilitas hasil penelitian. Analisis data menggunakan teknik Miles dan Huberman bahwa analisis dilakukan secara interaktif dan berlangsung terus menerus sampai tuntas, sehingga datanya jenuh mulai dari tahap pengumpulan data, tahap reduksi data, tahap data display, dan tahap verifikasi.

\section{HASIL DAN PEMBAHASAN}

\section{Tugas dan Peran Profesi Guru PAB}

Tugas dan peran guru PAB sangat beragam. Selain mengacu pada perundang-undangan yang berlaku, tugas dan guru $\mathrm{PAB}$ juga menyesuaikan dengan situasi dan kondisi yang dihadapi guru. Berdasarkan hasil wawancara 
dengan guru-guru PAB di Tangerang, diketahui bahwa tugas dan peran profesi guru $\mathrm{PAB}$ dalam hal pembelajaran adalah sebagai berikut: mengajar sesuai kurikulum seperti saat ini yang berlaku adalah kurikulum 2013, menjadi guru agama Buddha atau ada juga menjadi guru kelas di beberapa sekolah berciri Buddhis di Tangerang. Tugas guru dimulai dari merencanakan pembelajaran, melaksanakan pembelajaran, menilai hasil pembelajaran, memimbing dan melatih siswa, mengarahkan, aktif mendidik siswa, menyampaikan materi dan mempraktikkan materi, memotivasi anak supaya rajin baca jataka dan riwayat hidup Buddha. Secara administrasi, guru juga bertugas untuk membuat administrasi sebagai penilaian kedinasan, membuat perangkat pembelajaran (Silabus, RPP, Prota, Prosem).

Dalam hal membentuk karakter siswa uang baik guru PAB juga bertugas untuk membentuk karakter siswa, menanamkan budi pekerti, membangun keyakinan siswa, membangun citra baik siswa, menjadi teladan, mengembangkan kepribadian yang positif, mengubas kebiasaan anak menjadi positif, mencari inovasi pembelajaran. Dalam segi kemasyarakatan, guru PAB juga memiliki tugas pengabdian yaitu mengabdi kepada masyarakat atau sebagai Dharmaduta. Oleh karena itu, guru PAB juga memotivasi anak supaya rajin ke sekolah minggu agas siswa tidak hanya mendapatkan ilmu di kelas tetapi juga di vihara. Di Tengarang, jumlah vihara yang menyelenggarakan program sekolah minggu sangat banyak, jadi siswa dapat memilih sekolah minggu yang sesuai dengan minat dan kebutuhan belajar siswa.

Mengacu pada data di atas, tugas dan peran guru PAB tidak hanya menyampaikan ilmu pengetahuan agama Buddha dan membuat administrasi pembelajaran, namun juga bertugas membangun karakter yang berbudi pekerti luhur. Untuk itu, guru juga harus menyiapkan diri agar menjadi pribadi yang pantas diteladani. Menunjukkan kepedulian kepada siswa dengan cara membimbing, melatih, mengarahkan agar siswa tumbuh kembang menjadi manusia yang berilmu dan beragama. Pada aspek kemasyarakatan, guru agama Buddha melakukan pengabdian kepada masyarakat. Salah satu caranya adalah menjadi Dharmaduta yaitu berceramah di vihara-vihara atau menyampaikan Dharma kepada masyarakat.

\section{Permasalahan Profesi Guru PAB}

Berbagai permasalahan yang dihadapi profesi guru dapat dikelompokkan pada permasalahan pada siswa, permasalahan pada materi pembelajaran, permasalahan pada sarana dan prasarana, permasalahan pada administrasi pembelajaran. Terkait dengan permasalahan siswa, Guru PAB menghadapi beberapa persoalan mulai dari latar belakang keagamaan siswa, sikap dan kepribdain siswa, bekal belajar siswa, dan jumlah siswa. Permasalahan tersebut antara lain guru PAB mengajar siswa agama Buddha dari multi sekte sehingga guru juga harus memahami karaktersitik dan ajaran Buddha di antara sekte yang berkembang di Indonesia. Di Tangerang ada beberapa sekte atau aliran Buddhisme yang berkembang diantaranya Theravada, Mahayana, Buddhayana, Tri Dharma, Tantrayana. Oleh karna itu 
sangat penting bagi guru untuk memahami karakterisitik masing-masing aliran agar pada saat mengajar siswa yang dari berbagai sekte dapat melayani kebutuhan belajar siswa.

Guru PAB juga masih menghadapi siswa sulit diatur, siswa bertindak semau sendiri tanpa memperhatikan tata tertib saat pembelajaran, ini adalah contoh kepribadian siswa yang buruk. Masih ada anak belum bisa membedakan yang baik dan burukm sehingga di kelas dapat berperilaku yang tidak tepat, dan tugas guru $\mathrm{PAB}$ adalah memberikan pemahaman agar siswa menyadari bahwa bila yang diperbuat tidak baik akan menimbulkan masalah secara pribadi maupun sosial siswa.

Dari segi kuantitas siswa Buddha terutama yang di sekolah negeri, permasalah guru adalah jumlah murid yang semakin berkurang yang salah satu sebabnya adalah orangtua lebih suka memilih memasukan anak ke swasta. Sekolah negeri yang sudah menerapkan usia penerimaan siswa baru 7 tahun juga dianggap menjadi penyebab orangtua memilih menyekolahkan anak ke sekolah swasta Buddhis, sehingga di beberapa sekolah negeri guru hanya mengajar beberapa siswa yang beragama Buddha. Dampak dari jumlah siswa yang sedikit adalah penggabungan kelas agama Buddha. Dalam satu pertemuan guru mengajar Pendidikan Agama Buddha untuk kelas yang berbeda, sehingga guru akan sulit menentukan materi dan metode yang tepat saat pembelajaran. Permasalah lain yang muncul terkait umur siswa. Mengajar di kelas bawah memiliki tingkat kesulitan yang tinggi. Guru PAB yang mengajar di kelas bawah harus menyesuaikan dengan anak anak, sehingga pembelajaran kadang kala tidak berjalan sesuai dengan rencana yang ditetapkan. Butuh kesabaran dan pengertian guru dalam menyikapi perilaku siswa kelas bawah.

Permasalahan dalam bidang administrasi pembelajaran antara lain kesesuaian antara perangkat pembelajaran dengan kompleksitas karakteristik siswa. Guru harus paham terlebih dahulu dengan materi yang akan diajarkan dan karakteristik perkembangan siswa sehingga menjadi dasar dalam menentukan media pembelajaran yang akan dipilih dan metode pembelajara yang akan diterapkan. Pemberlakuan kurikulum 2013 juga memberi andil yang besar dalam pengerjaaan tugas administrasi guru $\mathrm{PAB}$, mulai dari menyusun rencana pembelajaran yang didalamnya terkandung rencana kegiatan mulai dari pembukaan, inti pembelajaran, dan penutup, serta kegiatan pendukung lainnya seperti media pembelajaran yang akan digunakan, dan evaluasi yang akan diterapkan.

Permasalahan dalam hal sarana dan prasarana pembelajaran adalah kurang buku panduan mengajar dan bahan belajar, dan ruang kelas yang kadang tak tersedia. Buku panduan mengajar yang sesuai dengan kurikulum 2013 belum sepenuhnya dimiliki guru. Masih ada guru yang belum memilikinya sehingga berdampak pada kesulitan dalam menerapkan kurikulum 2013. Bila guru tidak memiliki buku panduan mengajar, maka sulit untuk merancang kegiatan. Oleh karena itu sangat penting bagi guru untuk berinisiatif mengatasi setiap hambatan ketiadaan buku panduang mengajar. 
Misalnya ketiadaan buku panduan mengajar di sekolah dapat diatasi dengan cara meminjam buku panduan mengajar ke perpustakaan kampus yang menyediakan buku panduan mengajar PAB. Kelas yang berpindah-pindah untuk kegiatan PAB juga menjadi masalah karena guru dan siswa tidak bisa memasang hasil karya siswa di ruangan, pembelajaran menjadi dibatasi pada penyampaian materi saja.

Selain itu, kurangnya perhatian dari pemerintah juga menjadi permasalahan yang disampaikan guru. Di Tangerang masih banyak guru PAB yang belum mendapatkan hak menerima tunjangan sertifikasi guru. Hak-hak sebagai seorang pendidik belum sepenuhnya diterima oleh guru-guru PAB di Tangerang.

\section{Tantangan Profesi Guru PAB}

Tantangan dalam profesi guru berarti situasi yang mengharuskan guru menunjukkan kemampuan terbaik dalam upaya mengatasi permasalahpermasalahan yang timbul dalam melaksanakan tugas profesi. Mengacu pada pengertian tersebut, berdasarkan hasil wawancara dengan guru-guru PAB di Tangerang ada beberapa hal yang menjadi tantangan profesi diantaranya terkait dengan penguatan keyakinan siswa, pengajaran yang berkualitas, pembentukan karakter siswa, peningkatan kompetensi diri, jumlah siswa yang berkurang, dan sarana prasarana pembelajaran.

Guru memiliki tanggung jawab yang sangat besar untuk menguatkan keyakinan siswa pada Buddha Dharma. Kasus banyak anak yang pindah keyakinan menjadi tantangan bagi guru untuk memberikan bekal ilmu agar siswa menjadi mantap beragama Buddha. Di sisi lain, masih banyak sekolah di Tangerang yang belum menyelenggarakan pendidikan agama Buddha sehingga guru PAB yang memiliki siswa belum sama sekali mengenal agama Buddha atau siswa belum pernah belajar Pendidikan Agama Buddha harus memberikan pembelajaran secara bertahap. Di sisi lain, ada banyak anak mengaku beragama Buddha tetapi pengetahuan agamanya minim juga menjadi tantangan bagi guru dalam menyelenggarakan pembelajaran yang berkualitas untuk membekali siswa dengan pengetahuan-pengetahuan agama Buddha. Menyikapi situasi demikian, guru PAB perlu memaksimalkan waktu pembelajaran untuk memperkuat keyakinan siswa. Selain itu, dengan hadirnya teknologi dapat digunakan guru untuk membangun komunitas yang positif diantara siswa Buddha dalam rangka penguatan keyakinan yaitu membentuk grup online seperti lewat Whatsapps.

Berkaitan dengan pembentukan karakter, guru memiliki tanggung jawab untuk mengubah karakter siswa ke arah positif (seperti dari kikir jadi dermawan, cuek jadi ramah dengan orang lain, malas jadi rajin). Untuk itu sangat penting peran guru sebagai model dan teladan bagi siswa. guru tidak hanya pandai berteori tapi mampu menerapkan ajaran dalam kehidupan nyata yang bisa dilihat siswa.

Dalam hal kegiatan pembelajaran yang menarik perhatian siswa, guru harus menggunakan perangkat pembelajaran sesuai dengan kurikulum. 
Mengacu pada pendekaatan pembelajaran yang berlaku saat ini yaitu student centre learning sehingga aktivitas belajar lebih menekankan pada partisipasi dan peran aktif siswa. Berkaitan dengan peningkatan kompetensi diri, guru PAB harus mampu menyesuaikan diri di era modern, mampu menggunakan teknologi dalam pembelajaran. Teknologi adalah media pembelajaran sekaligus media sosial yang bila digunakan dengan tepat oleh guru akan mampu memberi efek yang positif dalam pembelajaran maupun interaksi dengan siswa.

Dari segi psikologi, guru harus mampu menjaga kesabaran, dalam menghadapi tingkah siswa yang kadang tidak tepat. Tidak semua rencana yang disusun saat akan mengajar terlaksana dengan baik, salah satu faktor penyebabnya adalah tingkah laku siswa. Menyikapi hal tersebut, kesabaran guru dibutuhkan terlebih dalam melakukan komunikasi dengan siswa yang bermasalah. Berkaitan dengan jumlah siswa, ada beberapa sekolah yang mengalami penurunan jumlah siswa. Ini menjadi salah satu indikator dari perkembangan agama Buddha turun, atau orang tua siswa lebih percaya dengan sekolah non Buddhis yang dianggap lebih baik. Bila situasi ini dibiarkan guru dapat mengalami masalah kekurangan siswa yang berimbas pada tunjangan sertifikasi bagi guru penerima tunjangan sertifikasi. Berkaitan dengan sarana dan prasarana yang kurang, ada beberapa guru PAB harus mengajar di ruang perpustakaan atau ruang kelas yang kosong. Hal ini karena jumlah siswa yang beragama Buddha sedikit. Untuk itu guru perlu belajar mengelola kelas kecil.

\section{Cara Menghadapi Tantangan Profesi Guru PAB}

Untuk manghadapi tantangan dalam menjalankan tugas profesi, ada beberapa cara yang dilakukan guru PAB. Untuk memperkuat keyakinan guru memberi tugas tambah pergi ke vihara ikut kegiatan sekolah minggu Buddha atau puja bakti.Terkait dengan aktivitas pembelajaran, guru menyusun rencana pembelajaran sebelum mengajar untuk menyiapkan pembelajaran yang berkualitas. Salah satu metode yang diterapkan guru adalah metode kooperatif dalam pembelajaran untuk menciptakan suasana pembelajaran yang kondusif diantara siswa maupun dengan guru. Guru memastikan agar siswa yang belajar agama Buddha benar-benar paham dengan materi yang diajarkan dengan cara mereviuw materi pembelajaran. Guru juga harus terus berinovasi dalam mencari dan menentukan media belajar yang kekinian agar menarik perhatian siswa saat pembelajarna.

Guru juga mengembangkan kesabaran dan kehati-hatian dalam menghadapi sikap siswa yang kurang pantas. Bagaimana pun siswa adalah seorang anak yang masih butuh bimbingan dari orang dewasa. Untu itu, kedewasaan guru dalam menyikapi tingkah laku siswa sangat dibutuhkan. Misalnya guru peka terhadap situasi di kelas, guru menyesuaikan pembelajaran dengan kondisi siswa, bila mengajar di kelas bawah guru harus masuk ke dunia siswa yaitu menyampaikan materi dengan menggunakan bahasa-bahasa sederhana dan contoh yang dekat dengan keseharian siswa. 
Berbagai permasalahan yang dihadapi guru merupakan tantangan yang memotivasi guru untuk melakukan tindakan yang terbaik dalam menyikapi berbagai persoalaan baik yang sifatnya internal maupun eksternal. Kemampuan guru dalam mengatasi berbagai tantangan merupakan salah satu indikator keberhasilan dalam menjalankan tugas profesi guru PAB.

\section{SIMPULAN}

Berdasarkan hasil penelitian dan pembahasan dapat disimpulkan bahwa tantangan profesi guru Pendidikan Agama Buddha di Tangerang adalah terkait dengan penguatan keyakinan siswa, pengajaran yang berkualitas, pembentukan karakter siswa, peningkatan kompetensi diri, jumlah siswa yang berkurang, dan sarana prasarana pembelajaran Setelah mengikuti berbagai kegiatan tersebut. Untuk mengadapi tantangan tersebut, guru PAB berusaha menyelenggarakan pembelajaran yang berkualitas melalui penggunaan metode pembelajaran kooperatif, penggunaan media pembelajaran yang kekinian, sabar dan hati-hati dalam menghadapi perilaku siswa, dan pemberian tugas tambahan pergi ke vihara ikut sekolah minggu Buddha atau puja bakti.

\section{DAFTAR PUSTAKA}

Danim, Sudarwan dan Khairil. 2013. Profesi Kependidikan. Bandung: Penerbit Alfabeta.

Fathurrohman, Pupuh dan AA Suryana. 2012. Guru Profesional. Bandung: Refika Aditama;

Kusaladhamma. 2009. Illustrated Chronicle of The Buddha. Diterjemahkan oleh Hendra Widjaja. Jakarta: Ehipassiko Foundation.

Mulyasa. 2009. Menjadi Guru Profesional: Menciptakan Pembelajaran Kreatif dan Menyenangkan. Bandung: Penerbit PT Remaja Rosdakarya

Permendiknas Nomor 16 tahun 2007 tentang Standar Kualifikasi Akademik Dan Kompetensi Guru

Sugiyono. 2012. Metode Penelitian Pendidikan Pendekatan Kuantitatif, Kualitatif, dan RED. Bandung: Penerbit Alfa Beta.

Undang Undang Nomor 14 Tahun 2005 Tentang Guru dan Dosen

Walshe, Maurice. 2009. The Long Discources of The Buddha A Translation of The Digha Nikaya (Khotbah-khotbah Panjang Sang Buddha: Digha Nikaya). Diterjemahkan oleh Team Giri Mangala Publicatioan dan Team DhammaCitta Press. Tanpa Kota: DhammaCitta 